\title{
Application of Management Audit for Increasing Economic Efficiency of State-Owned Enterprises Activities
}

\author{
Algis Junevicius, Rasa Daugeliene, Jurgita Jurkeviciene, Petras S. Orzekauskas - Nussbaum
}

\author{
Kaunas University of Technology \\ K. Donelaicio st. 73, LT-44029, Kaunas, Lithuania \\ E-mail.algis.junevicius@ktu.lt,rasa.daugeliene@ktu.lt,jurgita.jurkeviciene@ktu.lt,petras.orzekauskas@ktu.lt
}

cross'ref $^{\text {http://dx.doi.org/10.5755/j01.ee.28.4.17924 }}$

\begin{abstract}
To substantiate the direction of the research, this paper establishes the factors which affect performance efficiency of stateowned enterprises (SOES). The authors' analyse the effect of management control on the economic efficiency of activities of state-owned enterprises by application of management audit. The paper seeks to highlight the higher utility of economic activity as well as return of capital which was used in the process of activities. The paper analyses the quality of management and economic activity in SOEs based on scientific literature as well as reports and decisions of the representative government institutions as well as the results of empirical research which was accomplished in Lithuania. The paper stresses that the state-owned commercial property in Lithuania has thus far been managed inefficiently. Unlike private companies, SOEs practically fail to render much use to the state. This fact does not allow SOE's to reach the highest economic benefit. Accordingly, the authors' present an innovative approach towards the improvement of the management of SOEs economic activities through application of the audit principles, which traditionally are associated with the assessments of financial activity. The proposed model can be further extended and employed in other countries of Northern Europe, specifically in Latvia, Estonia and other Post-Soviet countries.
\end{abstract}

Keywords: State-Owned Enterprises (Soes), Management Audit, Economic Efficiency.

\section{Introduction}

As it was stressed in the work of Karapetrovic \& Willborn (1998), the success of a modern enterprise depends on numerous factors, which, if applied appropriately and reasonably, result in purposeful, economic, efficient and, above all, profitable activity. One such factor is the management of state-owned enterprises (SOEs), which greatly influences the economic efficiency of activities of these enterprises. Relevance of the research and the extent of investigation of the problem. There is a knowledge gap in consolidated literature or research works methodically analysing the issues of economic efficiency of management of SOEs. Researchers have largely focused on individual areas, such as the concept of an asset, classification, management and the transparency of SOEs (Karapetrovic \& Willborn, 1998; Nguyen, 2015; Ashraf \& Uddin, 2016; Chen, Cumming, Hou \& Lee, 2016; Reddy et al., 2016; Cochina, Arsenie, 2012). Within the context of an academic discussion, the issue of balance between the autonomy and control of SOEs has been analysed both in the works of foreign (Verhoest \& Rones, 2010; Flyvbjerg, 2008; Salkic, 2014; Yang, 2012; Ding et al., 2014; Ennser-Jedenastik, 2016) and Lithuanian (Nakrosis \& Martinaitis, 2011; Kloviene et al., 2015) authors. Their research has emphasized that employees of SOEs often lack management competence and are not adequately motivated to obtain the best results. Furthermore, state companies tend to employ excessive labour, and they are often coerced to employ management or employees motivated by political considerations, rather than the qualifications of the workers (Kowalski, 2013; Gaynor et al., 2016; Most, 1987) in their recent research defined financial reporting quality and audit quality, but they used a person/ task/ environment framework.

Sokol (2009), in his research, analysed the financing system and concluded that in many cases, faults in financing hinder efficient performance. These enterprises often receive from the state and municipalities credits and guarantees in the forms of direct subsidies, concessionary financing, statebacked guarantees, and preferential regulatory treatment, which in turn fail to stimulate the efficiency of SOEs. In addition to this favourable advantage of having government ownership, it can create an uneven playing field, ensuring that state-owned firms succeed. Therefore, by providing various benefits to SOEs that are not offered to private firms, the government can protect SOEs from competition (Capobianco \& Christiansen, 2011; Johnston \& Girth, 2012).

Experience with the theoretical and practical management of enterprises and organizations has shown that for successful improvement of economic activity of SOEs, it is necessary to assess their management and the constituent parts and processes of the company. The primary model, valid until now, fails to guarantee an acceptable final result. A functionally limited model, although it ensures better control and accountability, does not provide protection from excessive red tape or interference with the inner affairs of the enterprise. Representatives of the SOEs basically agree about the necessary changes, assessing the advantages and limitations of the model.

These facts inspire the scientific problem: how to improve economic efficiency of SOE's activity by application of management audit.

Object of the research: the assessment of economic efficiency of the activities of SOEs. 
Research aim: to analyse the possibility of application of management audit for increasing the economic efficiency of state - owned enterprises' activities.

The tasks to be solved: to search for approval of the necessity for the management of state-owned enterprises economic activities through management audit; to propose the model which would enable to develope the SOE's management process and would improve the economic efficiency of their activities by application of management audit.

The research methods applied include systemic analysis of scientific literature, comparative analysis of conceptions and statements, descriptive research, interview.

\section{The Search for the Management Model of State- Owned Enterprises Economic Activities}

In the countries of the Organization for Economic Cooperation and Development (OECD), the state has so far been a major owner of commercial enterprises. Under the conditions of competitive markets, such enterprises operate efficiently and further play important roles in the main infrastructure sectors. Therefore, one of the recommendations to the OECD is to have the overarching mission to ensure that it is acting in the public interest at all times - balancing the intended economic, social, and environmental outcomes, indicating that state-owned enterprises should take a longterm view and be transparent (Tophoff, 2014). The statistical data (Table 1) show that in the OECD countries, there were 2 085 state-owned enterprises in 2011. They employed approximately 4.5 million people, and their market value accounted for 1.5 billion USD. The research incorporated 27 of the 34 OECD countries (Christiansen, 2011).

Table 1

The Number of State-Owned Enterprises in OECD Countries

\begin{tabular}{|c|c|c|c|}
\hline Country & $\begin{array}{c}\text { Number of } \\
\text { SOEs }\end{array}$ & Employees & $\begin{array}{c}\text { Market value } \\
\text { (billions, USD) }\end{array}$ \\
\hline Australia & 17 & 48845 & 17.6 \\
\hline Austria & 9 & 79205 & 16.4 \\
\hline Belgium & 8 & 92361 & 57.8 \\
\hline Canada & 33 & 105296 & 21.6 \\
\hline Chile & 34 & 51728 & 13.1 \\
\hline Czech Republic & 124 & 166600 & 43.9 \\
\hline Denmark & 13 & 18508 & 10.7 \\
\hline Estonia & 54 & 25835 & 3.4 \\
\hline Finland & 36 & 91789 & 56.6 \\
\hline France & 51 & 838574 & - \\
\hline Greece & - & - & - \\
\hline Hungary & 358 & 152975 & 7.5 \\
\hline Israel & 29 & 50264 & 43.2 \\
\hline Italy & 25 & 289329 & 105.4 \\
\hline Japan & - & - & - \\
\hline Korea & 56 & 120655 & 177.6 \\
\hline Mexico & 68 & - & - \\
\hline Netherlands & 28 & 60355 & 74.1 \\
\hline New Zealand & 19 & 31852 & 18.8 \\
\hline Norway & 46 & 230195 & 131.0 \\
\hline Poland & - & - & - \\
\hline Portugal & 93 & 180577 & 18.3 \\
\hline Slovenia & - & - & - \\
\hline Spain & 151 & 160529 & 80.7 \\
\hline Sweden & 47 & 148132 & 67.7 \\
\hline Switzerland & 4 & 100128 & 33.3 \\
\hline United Kingdom & 21 & 378298 & 267.4 \\
\hline Total & 2085 & 4333670 & 1416.8 \\
\hline
\end{tabular}

Source: Compiled by the authors according to Christiansen, H. The Size and Composition of the SOE Sector in OECD Countries, OECD Corporate Governance Working Papers, 2011, No.5.
With regard to the 2014 report on the operation of SOEs, the Republic of Lithuania was the main shareholder or owner of 131 enterprises. These enterprises employed approximately 42000 employees, and the market value of these enterprises accounted for 40 billion euros (Activity of the Lithuanian SOEs, 2014). According to recent statistics, the number of Lithuanian SOEs in September 2015 amounted to 128 companies, which employed 41404 people, and the market value increased by $5.6 \%$, compared with the end of 2014 (Activity of Lithuania SOEs, 2015). Comparing these figures with Denmark and the Netherlands, which are small but economically well-developed countries, it may be said that the number of SOEs in Lithuania is rather large. Denmark, for example, has as many as 13 state-owned companies with 18 508 employees, and in the Netherlands, accordingly, the numbers of SOEs and employees are 28 and 60335 , respectively (Christiansen, 2011).

In 2014, Lithuania's SEOs were divided into four sectors: transport, energy, forestry and other enterprises, which incorporates enterprises not belonging to any of the first three sectors. Currently, the energy sector includes nine enterprises and owns the largest portion of the assets portfolio, i.e., approximately $47 \%$ (4.3 billion euros). The annual sales revenue accounted for $53 \%$ (1.2 billion euros) of the whole revenue portfolio in 2014. The transport sector runs 21 enterprises with $34.5 \%$ of the revenue portfolio. The forestry sector administers 42 forestry districts and the State Forest Management Institute. The assets of these enterprises account for $11.9 \%$ (1.1 billion euros), including commercial forests assessed by the Management Coordination Center of the analysed SOEs' assets, and the income accounts for $7.3 \%$ (167.6 million Euro) of the entire turnover portfolio. The other enterprises sector incorporates as many as 55 enterprises; however, the total sales income accounts for only $6.7 \%(154.3$ million euros) of the entire assets portfolio. The generated added value exemplifies the input of these enterprises into the state budget (Activity of the Lithuanian SOEs, 2014).

The practice of the management of enterprises has accumulated abundant evidence that the management of state property is a heavy-duty process. To increase confidence in SOEs, the OECD has recommended adopting transparent board nomination procedures and disclosure and reporting practices. In addition, the Council of the OECD has aimed to introduce domestic regulations through its Guidelines for Recipient Country Investment Policies Relating to National Security (Blyschak, 2011), which is related in many regards. States usually administer many different sectors with different enterprises, e.g., energy, transport or forestry. Each involves different management technologies, which require the formation of independent management systems and are regulated by legislation implemented by different state institutions. Managing multiple and potentially conflicting objectives is the main challenge in the governance of SEOs (Menozzi, 2012). As a result, the failure to create independent management systems can lead to detrimental results for morale and performance (By Maria Vagliasindi, 2008).

Another factor is the different centralization degree of different types of state property. An illustration may be that Lithuanian state roads are administered by 11 state enterprises according to trust law, and state-owned forests are managed by 42 state-owned forestries. In addition, the state has established different requirements and different goals for each 
enterprise. The situation stipulates that some enterprises in some cases tend to become a burden, both financially and politically (Baltic Institute of Corporate Governance and Frederic, 2012).

In this regard, states addressed the issues of management improvement several decades ago. One of the first countries to have reformed and focused on more professional, efficient and transparent management was Sweden. According to Dag Detter, one of the experts on SOEs, such enterprises, due to their subordination to several ministries or other public administration institutions, most often set different and even competing goals, and they experience acts of political interference, as well as a lack of transparency (Detter, 2006). The three pillars chosen by Sweden, i.e., isolation from excessive political interference, transparency and clear goals, were intended to ensure the success of the reform. Sweden chose the so-called centralized model, i.e., declared SOEs to be the property of one responsible ministry. At the same time, the holding company Stattum Inc. was established as the property of this ministry. In this manner, the shared responsibility of management became more transparent and clear, and the environment became more competitive, resulting in less political interference. The reform process occurred gradually from 1998 to 2001 .

One of the areas in which the EU seeks to enhance the efficiency of SOEs is the implementation of management rules. The EU refers to OECD practices and guidelines for more efficient governance (Corporate Governance of Stateowned Enterprises, 2005). All SOEs are obliged to follow principles of transparency, publicity of information, and responsibility of board members of the enterprise. Public enterprises should perceive high levels of transparency and should apply advantaged accounting, observance, disclosure and audit norms (OECD, 2015). Within the EU, the activities of SOEs are not regulated directly; rather, they are closely related to the regulation of state aid. Such aid implies the creation of more favourable conditions for one or several enterprises. A specific type of aid is support for providing services of common economic interest, which would be too difficult to provide without the state's contribution. Such services include transportation and postal and social services. However, such aid from the state has been subjected to severe criticism from other participants in the service market. Traditionally, government investments in state enterprises were justified based on the state's role in increasing national development; however, today, except for subsiding uneconomic services, such investments are prohibited by EUinspired anti-competition legislation (MacCarthaigh, 2009). As a result, to increase the efficiency of SOEs, EU institutions have resorted to measures comprising three levels. The first level incorporates the internal management of the SOE, i.e., monitoring of activity, preparation of reports, implementation of transparency measures and ensuring efficient work of boards. The second level is related to national measures, which include taxation, granting of subsidies and organization of public procurement. The measures of the third level incorporate more clear-cut regulations of state aid and the implementation of enterprise management guidelines. To establish these levels, it is important to perform a comprehensive analysis of the situation, to evaluate the overall economic situation of the country and to consult with the interested parties.
In Lithuania, SOEs are governed based on a decentralized model (The National Audit Report of the LR State Control, 2009). The model, however, for many Lithuanian enterprises does not translate into efficient management or good performance results mainly for the following reasons. SOEs often tend to apply inefficient and intricate management structures, some of which are even financed by the state budget. The founders of these enterprises do not provide proper supervision or control of management, organization and overall activity. Until September 2012, Lithuania lacked the necessary mechanism or a coordinating institution to provide efficient management and control, despite recommendations from the OECD, which maintains that in applying the decentralized management model, it is obligatory to establish a body to coordinate the policies of different ministries related to the supervision of SOEs and, accordingly, to be responsible for the creation and implementation of strategic guidelines. In September 2012, the Lithuanian government established the National Property Fund as a management coordination centre for SOEs. Before then, the supervision of SOEs was basically conducted through the analysis of performance results, thus neglecting the analysis of management and administration problems, which, according to management and administration theory and practice, significantly determine performance efficiency. These inefficiencies in performance in most cases were noted and stated, not by the founders but, rather, by the State Control Office (The National Audit Report of the LR State Control, 2009). However, the functions of the State Control do not involve assessment of the management and administration of SOEs. Its main responsibility is financial and activity audit. It provides decisions regarding the elimination of infringements, conclusions about state reports and preliminary investigations, which are confirmed by State Control reports, on the basis of which the activity of SOEs is assessed (LR State Control, 2014).

Every Lithuanian government has clearly and unambiguously declared the efficiency and management problems of SOEs. They have initiated numerous decisions regarding steps to improve the management of these enterprises. The search for the most effective management model has recently been conducted in two directions. The first is related to the main provisions of the state property management strategy for 2009-2016, which seeks more rational and efficient management of state property (LR Government decision on the centralized management of the state property, 2009). In terms of management, there is hope that the approved strategy will empower the institution (the Ministry of Finance) to shape general policies for property management, exploitation and disposal. However, its power to improve the legal framework, to govern the information systems of state property and to coordinate the preparation of reports on state property is rather limited. It would rather be called the function of the information centre within the state property management system.

The second direction is related to enhancing the efficiency of SOEs. In this regard, the LR government approved the following documents: Guidelines for Ensuring Transparency of State-owned Enterprises (Decision of the LR Government on the approval of the transparency guidelines for the activity of state-owned enterprises, 2010), The conception of enhancing the efficiency of the SOEs (Decision 
of the LR government on the conception of enhancing efficiency of the state-owned enterprises, 2010) and The program of 2011-2012 for the reconstruction of state-owned enterprises (Decision of the LR Government on the program of 2011-2012 for the reconstruction of the state-owned enterprises). These documents established the main principles and guidelines for reconstruction: ensuring transparency, detachment of property and regulation functions, appointment of professional members of boards independent of political interests, and establishment of clear-cut goals and financial results for the enterprises and control of their realization. The Ministry of Economics is in charge of these areas. In 2015, the government approved an important document, the National Reform Agenda (Lithuania: 2014. National Reform Agenda, 2014). It consolidated the main structural reforms seeking to meet the quantitative goals of the strategy "Europe 2020". The document was prepared with a focus on the Lithuanian progress strategy "Lithuanian 2030" (The Seimas of the Republic of Lithuania, 2012). The National Reform Agenda (NRA) paid much attention to SOE management reform, aiming to increase the efficiency and transparency of SOEs, as well as to improve the principles of corporate governance (Ministry of Economic Development and Trade of Ukraine, 2016). This reform provides the potential to optimize the efficiency of their activities, to attract investments and to increase state budget profits (Ministry of Economic Development and Trade of Ukraine, 2016).

The analysis performed suggests that these documents and reports are declarative in nature. They are intended to improve the performance results of SOEs; the recommendations, however, fail to initiate cardinal and necessary administration and management reform. Unlike private companies, these enterprises do not render any practical benefit for the state (Boardman, Vining \& Weimer, 2016; Ho, Lin \& Tsai 2016). The governance structures of the state enterprises are intricate, employing many administrative workers, many of whom are subsidized by the state.

The founders do not control or supervise management or administration. The enterprises are subjected to severe criticism because of their limited profitability and the lack of publicity in decision making and monitoring. Private companies tend to attain greater management performance because the shareholders incorporate the costs of monitoring and implement more efficient management control than SEOs, in which supervision is in the hands of bureaucrats (Kowalski1, Buge \& Sztajerowska, 2013). However, although the legal framework regulating the management and activity of SOEs is more developed than that in private companies, it does not guarantee the efficiency or quality of management and administration. It must be noted that the consequent obscurities of the legal acts (LR law on the state and municipalities-owned enterprises, 1994) also contribute to the situation. One of the disadvantages of these acts is that they lack precise and definite regulations of the administrative bodies of the SOEs. The acts fail to establish procedures for the appointment of the enterprises' management or the formation of their boards. The law does not provide for the formation of supervisory boards; they, however, do exist in some enterprises.

Based on international practice and the performed research, it can be stated that one of the reasons for the inefficiency is the existing management system, which in no way stimulates profitability but has ambiguous goals. This situation creates conditions for failure. As in many other countries, in Lithuania, the ties of state-owned business enterprises (SOBEs) to the government are rather close and subordinate to some ministries, which protect them from external competition. Although the principal function of these ministries should be regulation of the activity of relevant sectors, the ministries often resort to active participation in the management of SOBEs. Such actions diminish transparency and worsen the financial results, leading to unavoidable conflicts of interests.

\section{Management Audit and it's Application}

Explanation of the fundamental terms. The worldwide practice of theoretical and practical experience in the management of enterprises and organizations have shown that to successfully improve the management of SOEs, it is necessary to assess the management of the enterprises and its constituent parts, as well as processes, by applying the principles of audit to the management and administration. Comparative analysis of the concept of "audit" showed that the definition of an audit is most often related to the assessment of financial activity. The start of the legalization of the control and assessment mechanism was in 1845, when the United Kingdom adopted laws on the basis of which companies are obliged to commission independent accountants to inspect their accounting books and accounts and to present the inspection results to shareholders. Later, the application of audit was introduced in the USA, when, in 1887, the Auditors' Association was established. In theory and practice, the concept of "auditio" (audit activity, audit, i.e., checking, revising) indicates the independent inspection of financial reports (expertise) and the formation of opinions about them (Orzekauskas \& Smaiziene, 2009; Hall, 2014). A similar concept of "audit" is presented in the law on audits passed by the Seimas of the LR in 1999, in which audit is described as a process intended to reduce the information risk for consumers. Often, the concept of "audit" is directly used as the synonym for "control", "revision", or "checking". Today, audit is perceived as a function that serves accountability because it adds credibility to the assertions of the entity rendering its accounts, and it creates valuable insights into and information about the entity conferring the responsibility (Dye \& Stapenhurst, 1998).

Based on the current practice of the application of audit as a method of activity assessment, as well as on theoretical works, it is possible to maintain that this concept barely corresponds to the real situation because financial audit is only one type of audit, which is relevant for the Lithuanian case because Lithuanian laws are currently designed to regulate audit and actually regulate financial control.

In recent years, however, when the importance of management and its effects on performance results have increasingly grown, the audit of governance and administration management (or management audit in a general sense) has been actualized and highly encouraged. Despite dramatic changes in audit in Lithuania, the analysis of theoretical and practical experience suggests that the current understanding of "audit" is obsolete, first due to its narrow range of application and use. It is mostly focused on the area of finance, and it fails to establish tangible reasons 
for poor performance, which result from faults in management and administration.

The main aim of management audit is to assess an organization's management system, its methods and its influence on performance results. The procedure of such an audit, however, is a more complicated process than that of financial audit.

The origins of management audit, which was formed as scientific discipline with explicit environment of it's application (e. g. Bjorson firm), as it was stress by Cochina, Arsenie (2012), were presented about the years of 1932 in Great Britain, when TG Rose published the work "The Management Audit". However, valid development of it's application in practice was not carried out.

It is important to stress, that some of the authors, rise of management audit correlate with the evolution of financial audit and legal acts requirements. This make influence to the interests of enterprises in order to improve their management process as well as achieve economic prosperity (Most, 1987).

According to Wubbelmann (2001), topics of management audit was started to be developed in USA, as well as in Canada and Australia in the begining of 1950s. The attention to the management audit in Germany rised in the beginning of 1980s. The main reason for such studies was rapid and progressive development of state 's industry and business. The situation provoke to increase the efficiency of management, enabled to improve activities results, herewith to guaranty the higher utility of economic activity. It is important to stress, that application of management audit in Lithuania still is in stagnation stage (Orzekauskas \& Smaiziene, 2009).

From the economic perspective, interrelation betwen utility of management audit and improvement of the results of enterprise's and organisation's activities is obviouse and undisputed (Karapetrovic \& Willborn, 1998). Management audit is very significant measure not only in the basic essence which stipulates to improve the efficiency of enterprises management. It is the precondition to seek for more usefull economic results of different activities (Brender et al., 2015). Such audit can provide significantly expanded and detailed benefit. E. g., stipulate leadership, to evaluate risk of management in details as well as the maturity of organisations (Roncea, 2016).

As it was stressed in works of Burrowes \& Persson (2000) and Brender, Yzeiraj \& Fragniere (2015), currently, management audit, as effective instrument of development of enterprises management, is succesfully applied in different coutries. Management audit is applied assessing the level of management of public sector institutions. The assessment correlates with the aspects of economy and effectiveness (Desmedt, Morin, Pattyn \& Brans, 2017) (Loke et al., 2016). Especially it is actual for the manufactoring enterprises (Platts \& Gregory, 1990).

For the efficiency and quality of management audit (Karapetrovic \& Willborn, 2000) the very important influence makes its' methodology, applied models, conceptions and forms, the principles of organisation and implementation, formation of audit teams as well as their preparation for auditing (Elder de Aquino, 2008; Arter, 2000; Wubbelmann, 2009).

The main aims of the management audit, incorporating management and administration organization areas, must be the following:
- to identify the present level and state of management and administration processes of the present management structure and the administration system of the organization;

- in identifying their influence on the overall activity and results of the organization, to analyse and assess simultaneously the management and administration documents of the organization and its structural subdivisions and workforce;

- to analyse and assess all of the legal documents of external and internal origin regulating the management, administration and activity of the organization;

- to identify their state, efficiency and validity in analysing and assessing the real levels of management and administration of the organization; and

- to analyse, to assess and to establish the reasons for the present level of management, state, expedience, necessity and efficiency of the management structure and administration system, as well as to devise a program for the necessary transformations and actions, on the basis of which the optimization of the management of the organization may be possible, based on the ratio of the sought or set utility and finances assigned for management (Hale \& Whitlam, 2000).

It is important to emphasize that not only does the institutionalizing of comprehensive audits provide advantages for SEOs, but audits can also provide some disadvantages for an organization. First, the audit is costly, and it distracts managers' attention from managing the enterprise. Second, there is the potential of the audit to create an audit anticipation effect, forestalling the pursuit of objectives that the government (or management) sees as improper. Moreover, in a parliamentary regime, audits can be less effective if the government in power controls the parliament.

Analysis shows that the audit of the management of Lithuanian business enterprises, specifically of SOEs, has rarely been applied thus far. This situation is determined by several factors. First, the conception of this type of audit has not yet been defined. Moreover, the main obstacle for this audit is that systems and procedures established by the state are nonexistent. With regard to the provisions described above, the aim of this empirical research is to assess the management of SOEs and their constituent parts in a holistic manner by applying the principles of audit of management and administration.

\section{Research Methods and Results}

The research subjects are SOEs (Public enterprises, $\mathrm{UAB}$ and $\mathrm{AB}$ ) and their founders, including ministries, the State Property Fund and the municipalities' property funds. The period of research is 2015 .

The research methods. In assessing the research object, descriptive research was used by applying a questionnaire survey. The research used two questionnaires. The first was designed for SOEs (public institutions, $\mathrm{UAB}$ and $\mathrm{AB}$ ), i.e., the first group, while another was designed for the founders of these enterprises (ministries, municipalities and the State Property Fund), i.e., the second group. The questionnaire for each group of respondents was focused on the area of the group members' competence. The specialists within the questioned ministries and organizations were identified as experts, which was a way to increase the motivation for 
participation by dissociating them from personal experiences. Of 144 questionnaires intended for state enterprises (1st group), 140 questionnaires were completed, indicating that possible and tolerated error accounted for $2.77 \%$. Of 69 questionnaires sent to the 2 nd group, 65 were returned, so the possible deviation was approximately $5.7 \%$. For assessment, percentage expression and a five-rank scale were used ( 1 is the lowest grade, 5 is the highest).
Results of the research. The questions presented to the respondents were divided into 3 groups. The questions asked of the $1^{\text {st }}$ group were designed to reveal the attitudes of the founders and representatives of the SOEs towards the problems of management and administration systems. The frequency of selection of particular problems that are important to respondents are presented in Table 2. As the research results show, not the same problems are important in different enterprises.

Table 2

Problems of Management and Administration System According to the Representatives of SOEs and the Founders of these Enterprises

\begin{tabular}{|c|c|c|}
\hline Problems founders & $\begin{array}{l}\text { Answers from the } \\
\text { SOEs }(\%)(1 \text { st group) }\end{array}$ & $\begin{array}{l}\text { Answers from the } \\
\text { SOEs }(\%) \text { (2nd group) }\end{array}$ \\
\hline The system of management and administration is not clear-cut, logical or understandable. & 0 & 6 \\
\hline The management structure is obsolete and does not meet the current situation. & 0 & 12 \\
\hline Professional guidance is not provided. & 7 & 18 \\
\hline $\begin{array}{l}\text { The system of management and activity, comprising databases and their management, is } \\
\text { inefficient. }\end{array}$ & 3 & 24 \\
\hline The planning, organization, management, supervision and control of works are inefficient. & 0 & 12 \\
\hline The efficiency of internal and external communication processes is not ensured. & 3 & 18 \\
\hline $\begin{array}{l}\text { Communication barriers between managers and employees and intricate channels of } \\
\text { communication lead to management inefficiency. }\end{array}$ & 0 & 12 \\
\hline The possibilities for united, systematic, continuous management are not guaranteed. & 0 & 12 \\
\hline $\begin{array}{l}\text { An efficient system of measurement, assessment and analysis of management and } \\
\text { administration is not ensured. }\end{array}$ & 0 & 6 \\
\hline The system of responsibility and self-control of the employees is inefficient. & 13 & 24 \\
\hline The employees are not responsible for the performance results of the enterprise. & 7 & 29 \\
\hline The motivation system is inefficient. & 27 & 35 \\
\hline The staff management is inefficient. & 0 & 35 \\
\hline The quality management system is inefficient. & 10 & 0 \\
\hline Efficient distribution of works and functions is not ensured. & 0 & 6 \\
\hline $\begin{array}{l}\text { The system of management and administration does not provide efficient management of } \\
\text { human, financial and technological resources. }\end{array}$ & 3 & 6 \\
\hline $\begin{array}{l}\text { The system of management and administration does not provide implementation of the } \\
\text { enterprise strategy. }\end{array}$ & 0 & 6 \\
\hline $\begin{array}{l}\text { Engagement of the employees in the management and activity of the enterprise is not } \\
\text { ensured. }\end{array}$ & 7 & 0 \\
\hline There is a lack of workers competent in management and teamwork. & 17 & 12 \\
\hline The employees do not exhibit initiative to improve the management system. & 13 & 29 \\
\hline $\begin{array}{l}\text { The initiative shown by employees to improve the management system is accepted } \\
\text { negatively or not encouraged. }\end{array}$ & 10 & 41 \\
\hline
\end{tabular}

Source: Compiled by the authors according to the research data

The comparison of answers supplied by SOE representatives and their founders showed that the founders, in assessing the problems of management and administration, revealed more problems than the representatives of the enterprises. The attitudes of SOEs were less critical. The founders indicated the following problems ( $2^{\text {nd }}$ group of respondents): professional management is not ensured (18\%); the system of selfcontrol and responsibility is inefficient (24\%); the employees are not responsible for the overall results (29\%); the motivation system is inefficient (35\%); and staff management is inefficient $(35 \%)$. The representatives of the SOEs ( $1^{\text {st }}$ group) failed to see any problems in staff management $(0 \%)$. The founders also said that there was a shortage of employees who were good at management and were able to work on teams $(12 \%)$. The SOE representatives agreed $(17 \%)$. Additionally, according to the founders, the employees do not exhibit initiative to improve the management system. The founders were most critical of the initiative of improvement. They maintained that the initiative was accepted negatively and was not encouraged $(41 \%)$. Only $10 \%$ of SOE representatives assessed this situation negatively. Based on the survey results, it can be stated that the SOE representatives were not willing to be critical of their activities. They negatively assessed the system of motivation (27\%).

In summarizing the results when assessing the systems of management and administration, it is more relevant to trust the assessments of the founders because, in all aspects, they are willing to disclose the problems.

The second group of questions was designed to clarify how the SOE representatives ( $1^{\text {st }}$ group) and their founders ( $2^{\text {nd }}$ group) assessed the system of management and administration and its constituent parts (Table 3). Referring to the results obtained using the 5-rank system (1 is the lowest score, 5 is the highest), we can state that both the representatives of SOEs and the founders in assessing individual parts of the system were sufficiently critical. The assessment average of the SOEs was only 3.89, and that of the founders was only 3.27. Comparing the answers of both groups, we found that the founders in assessing individual parts of the system, as well as in assessing the problems, were more critical than the SOE representatives. 
Assessment of the Parts of Management and Administration (on a scale of 1-5)

\begin{tabular}{|c|c|c|}
\hline Parts of management and administration & $\begin{array}{c}\text { Summarized } \\
\text { averages of SOEs } \\
\text { (1st group) }\end{array}$ & $\begin{array}{c}\text { Summarized } \\
\text { averages of the } \\
\text { founders }\end{array}$ \\
\hline Management and administration system & 4.13 & 3.47 \\
\hline Management structure & 4.20 & 3.59 \\
\hline Management professionalism & 4.27 & 3.59 \\
\hline Information system of management and performance & 3.83 & 3.19 \\
\hline $\begin{array}{l}\text { The system of planning, organization, management, supervision, analysis and control of the activity and } \\
\text { works of the enterprise }\end{array}$ & 4.07 & 3.24 \\
\hline The system of internal and external communication & 3.83 & 3.18 \\
\hline Possibilities for unity, organization and continuity of management and activity of the enterprise & 4.07 & 3.59 \\
\hline The system of measurement, assessment and analysis of management and administration & 3.69 & 3.00 \\
\hline The system of responsibility and self-control of the employees & 3.63 & 3.00 \\
\hline The employees' responsibility for the results of the enterprise & 3.67 & 2.94 \\
\hline Staff management & 4.03 & 3.35 \\
\hline Motivation system & 3.37 & 3.12 \\
\hline Distribution of works and functions & 4.14 & 3.41 \\
\hline Management of the available human, financial, technical and technological resources & 3.90 & 3.41 \\
\hline Involvement of the workforce at all levels of the management and activity of the enterprise & 3.50 & 3.00 \\
\hline Employees' competence and abilities in management & 3.97 & 3.29 \\
\hline Generalized average & 3.89 & 3.27 \\
\hline
\end{tabular}

Source: Compiled by the authors according to the research results

The founders were sufficiently critical of many parts of the management and administration system: the information system of management and activity was assessed a score of 3.19 ; the system of activity, planning, organization, management, supervision, analysis and control - 3.24; the system of internal and external communication - 3.18; staff management $-3.35 \%$; and employees' competence and management skills -3.29 . Even more critically assessed were parts with assessment scores of 3 or less. For example, the system of measurement, assessment and analysis of management and administration was assessed a score of 3 or less; the system of responsibility and self-control of the employees - 2.94; and the engagement of employees in all levels of the management and activity of the enterprise 3.00. The founders, in a general assessment of the system of management and administration, assessed a 3.47. Similar assessments were offered of the management structure (3.59) and the professionalism of management (3.59). Practically, the representatives of SOEs assessed all of the positions much more positively, i.e., with higher scores, with differences of at least 0.31 (with the exception of the motivation system).

Table 4

The areas of Improvement of the Management and Administration System

\begin{tabular}{|c|c|c|}
\hline Management and administration areas to be improved & $\begin{array}{c}\text { Response by the } \\
\text { SOEs representatives } \\
\text { (1st group, \%) }\end{array}$ & $\begin{array}{c}\text { Response by } \\
\text { the founders } \\
\text { (2nd group, \%) }\end{array}$ \\
\hline To improve the entire system of management and administration of the organization in complex manners & 27 & 35 \\
\hline To improve management professionalism & 20 & 35 \\
\hline $\begin{array}{l}\text { To improve the information system of management and activity comprising databases and their } \\
\text { management (regular implementation of innovative IT) }\end{array}$ & 53 & 41 \\
\hline $\begin{array}{l}\text { To improve the planning, organization, management, supervision and control system of works and to } \\
\text { ensure their efficiency }\end{array}$ & 17 & 47 \\
\hline To improve the internal and external communication system & 20 & 18 \\
\hline To improve the organization and continuity of management and administration & 10 & 18 \\
\hline To improve the system of management, administration, measurement, assessment and analysis & 17 & 35 \\
\hline $\begin{array}{l}\text { To strengthen the control and management of administration on the basis of self-control and responsibility } \\
\text { for better performance results of the enterprise }\end{array}$ & 13 & 29 \\
\hline $\begin{array}{l}\text { To provide encouragement of the employees' self-control and responsibility for the general results of the } \\
\text { enterprise }\end{array}$ & 53 & 29 \\
\hline To change the current motivation system & 17 & 24 \\
\hline To improve the distributions of work and functions & 40 & 12 \\
\hline To improve the system of quality management & 20 & 0 \\
\hline To enhance the engagement of all employees in the management and activity of the enterprise & 20 & 12 \\
\hline To provide training to improve competence in management and teamwork & 43 & 24 \\
\hline
\end{tabular}

Source: Compiled by the authors according to the research data

The assessment of the opinions of the founders and SOE representatives regarding what should be improved in management and administration systems was also the focus of attention in the research ( $3^{\text {rd }}$ group of questions). As seen from the results in Table 4, it can be maintained that the SOE representatives, while suggesting the areas of SOE management and administration that need to be improved, expressed higher necessity than the founders. The necessity to improve the information system of management and activity, consisting of databases and their management (regular implementation of innovative IT), was approved by as much as $53 \%$ of the SOE representatives compared to 41 $\%$ of the founders. Fifty-three percent of the SOE representatives favoured stimulating the employees' responsibility and self-control for the best performance results of the enterprise, while the founders accounted for 
only $29 \%$. The necessity to improve the distribution of functions and work received approval from $40 \%$ of the SOE representatives, and the necessity to organize training for better management competence and teamwork was approved by $43 \%$ of SOE representatives, leading to the conclusion that a rather large number of SOE representatives were in favour of improving the system (in some positions, more than $53 \%$ ) because the issue was about improvement but not about the identification of shortcomings of the system that they assessed and of which they were acting members.

\section{The Model for SOEs Management and Administration Improvement}

The results of empirical research provide the possibility to present a model for the improvement of the management and administration of SOEs. Based on the analysis and the obtained results of the empirical research, it can be maintained that to improve the management and administration of SOEs, it is necessary to conduct management audits, the model for which is represented in Figure 1, in a holistic manner. Audit consists of nine stages.

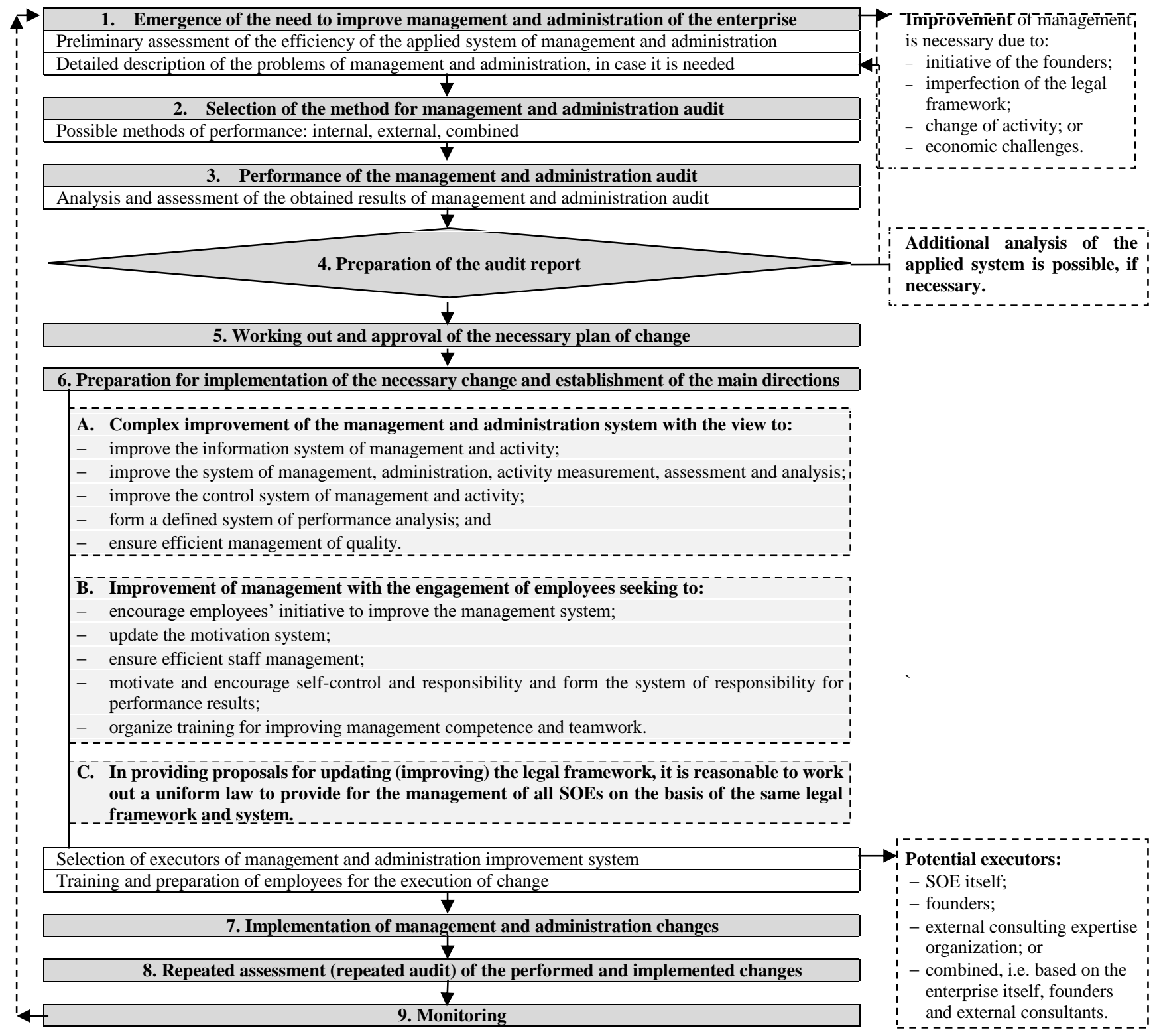

Figure 1. The Model for SOE's Management and Administration Improvement

The process of management improvement must start with the need to improve the management and administration systems of enterprises. When the need for change is evident, it is relevant to assess the appropriateness and efficiency of the existing system and to identify definite problems in the management and administration. In the second stage, it is necessary to decide who will perform the audit of management and administration. The audit can be performed by the available staff of the enterprise, by employing external specialists, or in a combined fashion by creating a joint team. In the third stage, it is appropriate to perform the audit of management and administration. This stage is the most important. Then, all of the information about management and administration is collected, assessed and analysed. Following the analysis and assessment of the audit results is the fourth stage, in which the report is prepared. On the basis of that report, in the fifth stage, a plan for future changes is prepared and approved. In the sixth stage, the plan for the implementation of changes is approved. It incorporates the selection of people who will execute the improvement of management and administration and the training of staff to be engaged in the process. In this stage, it 
is of the utmost importance to create a proper psychological climate and to encourage willingness to make changes. The enterprises and their founders can initiate improvements, either on their own by employing an external consultation company or by creating a joint team. In any case, it is important to ensure maximal engagement of the entire workforce in the enterprise.

In the seventh stage, all of the planned changes in management and administration are to be implemented. An additional assessment of the changes after implementation is obligatory, with the goal of identifying their efficiency and utility. The eighth stage involves repeated assessment of the implemented changes. The last stage, i.e., the monitoring stage, is performed with the view towards preventing distortion of the new system of management and administration. The prepared model is universal and can be applied for all SOEs regardless of their management form and subordination. However, this model can be and should be individualized, if necessary, according to the needs of the enterprise, the capacity and competence of the staff, etc.

The research results proved the hypothesis that different representatives of the SOE system assess the advantages and disadvantages of the SOE management model differently; however, in principle, they welcome the necessary changes.

\section{Conclusions}

The theoretical and practical analysis showed that the management and organization of enterprises are very important processes, with great influence on performance results. The economic efficiency and quality of these processes is the main guarantee of success because the information gathered forms a vital base for future actions. Efficient management and administration alone can produce superior results, which, as the analysis showed, are very important for SOEs.

Improvements can be attained through a management audit, which requires the enterprise to implement and adhere to a basic information system and routine control procedures and to develop targets for economic efficiency and effectiveness. In addition, the research results showed that in Lithuania, state-owned commercial property has thus far been managed inefficiently, in many cases determined by inefficient management and administration of SOEs. Unlike private companies, SOEs practically fail to render much use to the state. To change the situation radically, it is necessary to improve the management and administration of these enterprises. They must be more efficient, more innovative and transparent, and more reliable and must have minimized management structures managed by specialists and not by the interests of the majority parties.

To achieve changes in the area of the management of SOEs, it is necessary to assess their levels of management and organization by applying the complex method based on management audit. The audit should not only consist of troubleshooting financial audits but should also be conducted on a great variety of measurements, such as scheduling, transportation, security, human resources, capital operations, management ethics and culture and so forth. In addition, this audit can be performed and economic efficiency could be rised by applying the assessment and improvement model of management and administration, developed on the basis of this paper. This model could be interpreted as theoretical contribution of the research.

The proposed model is universal and can be applied in all state-owned business enterprises regardless of their management form or subordination.

\section{References}

Arter, D. R. (2000). Management Audit: A Result-Oriented Audit Can Provide the Impetus for Positive Change. Available from internet: http://www.qualitydigest.com/magazine/2000/apr/article/management-auditing.html.

Ashraf, J., \& Uddin, S. (2016). New Public Management, Cost Savings and Regressive Effects: A Case from a Less Developed Country. Critical Perspectives on Accounting, 41, 18-33. http://doi.org/10.1016/j.cpa.2015.07.002.

Asian Development Bank (2012). Finding Balance. Available from internet: http://www.adb.org/sites/default/files/ publication/ 29988/finding-balance-benchmarking-performance.pdf.

Baltic Institute of Corporate Governance (2012). Governance of State-owned Enterprises in the Baltic States. Available from internet: http://corporategovernance.lt/uploads/docs/Governance\%20of\%20State-owned\%20Enterprises $\% 20 \mathrm{in} \% 20$ the $\% 20$ Baltic\%20States.pdf.

Baltic Institute of Corporate Governance (2013). CEOs in Lithuanian State-owned Enterprises. Available from internet: http://www.corporategovernance.lt/uploads/docs/CEOs\%20in\%20Lithuanian\%20State-Owned\%20Enterprises.pdf.

Blyschak, P. (2011). State-owned Enterprises and International Investment Treaties: When Are State-owned Entities and Their Investments Protected? Journal of International Law and International Relations, 6(2), 1-52.

Boardman, A. E., Vining, A. R., \&Weimer, D. L. (2016). The Long-Run Effects of Privatization on Productivity: Evidence from Canada. Journal of Policy Modeling, 38 (6), 1001-1017. http://doi.org/10.1016/j.jpolmod.2016.04.002.

Brender, N., Yzeiraj, B., \& Fragniere, E. (2015). The Management Audit as a Tool to Foster Corporate Governance: An Inquiry in Switzerland. Managerial Audit Journal, 30(8/9), 785-811. http://dx.doi.org/10.1108/MAJ-032014-1013.

Burrowes, A., \& Persson, M. (2000). The Swedish Management Audit: A Precedent for Performance and Value for Money Audits. Managerial Audit Journal, 15(3), 85-97. http://dx.doi.org/10.1108/02686900010319348.

Capobianco, A., \& Christiansen, H. (2011). Competitive Neutrality and State-owned Enterprises: Challenges and Policy Options. OECD Corporate Governance Working Papers, 1. Available from internet: http://observgo.uquebec.ca/ observgo/fichiers/65274_ep2.pdf.

Chen, J., Cumming, D., Hou, W., \& Lee, E. (2016). CEO Accountability for Corporate Fraud: Evidence from the Split Share Structure Reform in China. Journal of Business Ethics, 138(4), 787-806. doi:10.1007/s10551-014-2467-2. 
Algis Junevicius, Rasa Daugeliene, Jurgita Jurkeviciene, Petras S. Orzekauskas - Nussbaum. Application of Management...

Christiansen, H. (2011). The Size and Composition of the SOE Sector in OECD Countries. OECD Corporate. Governance Working Papers, 5. Available from internet: http://dx.doi.org/10.1787/5kg54cwps0s3-en.

Cochina, I., \& Arsenie, C. (2012). Management of an Audit Organization and Audit of Management. In Proceedings of the 6th International Management Conference "Approaches in Organisational Management", Bucharest, Romania, 89-95.

Desmedt, E., Morin, D., Pattyn, V., \& Brans, M. (2017). Impact of Performance Audit on the Administration: A Belgian Study (2005-2010). Managerial Audit Journal, 32(3), 251-275. http://dx.doi.org/10.1108/MAJ-042016-1368.

Detter, D. (2006). The Swedish Reforms of State-owned Enterprises - A Case Study in Corporate Governance. Available from internet: http://www.detterco.com/the-swedish-reforms-of-state-owned-enterprises-a-case-study-incorporategovernance.htm.

Ding, S., Jia, Ch., Wu, Z., \& Zhang, X. (2014). Executive Political Connections and Firm Performance: Comparative Evidence from Privately-Controlled and State-Owned Enterprises. International Review of Financial Analysis, 36, 153-167. http://doi.org/10.1016/j.irfa.2013.12.006.

Elder de Aquino, C. (2008). Six Steps to an Effective Continuous Audit Process. Available from internet: https://iaonline.theiia.org/six-steps-to-an-effective-continuous-audit-process.

Ennser-Jedenastik, L. (2016). The Politicization of Regulatory Agencies: Between Partisan Influence and Formal Independence. Journal of Public Administration Research and Theory, 26(3), 507-518. https://doi.org/10. 1093/jopart/muv022.

Ernst \& Young. (2010). Government as Best in Class Shareholder: Featuring the Point of View of 12,000 Citizens in 24 Countries. Available from internet: http://www.ey.com/Publication/vwLUAssets/Government_as_is_best_class_ shareholder/\$FILE/Government\%20as\%20in\%20best\%20class\%20shareholder_FINAL.pdf.

Flyvbjerg, B. (2008). Curbing Optimism Bias and Strategic Misrepresentation in Planning: Reference Class Forecasting in Practice. European Planning Studies, 16 (1), 3-21. http://dx.doi.org/10.1080/09654310701747936.

Gaynor, L. M., Kelton, A. S., Mercer, M., \& Yohn, T. L (2016). Understanding the Relation between Financial Reporting Quality and Audit Quality. Audit-A Journal of Practice\&Theory, 35 (4), 1-22. http://dx.doi.org/10.2308/ajpt-51453.

Hale, R., \& Whitlam, P. (2000). Powering Up Performance Management: An Integrated Approach to Getting the Best from Your People. Brookfield: Gower Publishing.

Hall, J. A. (2014). Accounting Information Systems ( $9^{\text {th }}$ ed.). Boston: Cengage Learning.

Ho, P. H., Lin, C. I., \& Tsai, W. C. (2016). Effect of Country Governance on Bank Privatization Performance. International Review of Economics \& Finance, 43, 3-18. http://doi.org/10.1016/j.iref.2015.10.028.

Johnston, J. M., \& Girth, A. M. (2012). Government Contracts and 'Managing the Market': Exploring the Costs of Strategic Management Responses to Weak Vendor Competition. Administration \& Society, 44(1), 3-29. http://dx.doi.org/10.1177/0095399711417396.

Karapetrovic, S., \& Willborn, W. (1998). Integrated Audit of Management Systems. International Journal of Quality \& Reliability Management, 15(7), 694-711. http://dx.doi.org/10.1108/02656719810218220.

Karapetrovic, S., \& Willborn, W. (2000). Generic Audit of Management Systems: Fundamentals. Managerial Audit Journal, 15(6), 279-294. http://dx.doi.org/10.1108/02686900010344287.

Kloviene, R., Gimzauskiene, E., \& Misiunas, D. (2015). The Significance of SOEs Performance Measurement as Policy Instrument in Baltic Countries. Procedia - Social and Behavioral Sciences, 213(1), 286-292. https://doi.org/10. 1016/j.sbspro.2015.11.539.

Kowalski1, P., Buge, M., \& Sztajerowska, M. (2013). State-owned Enterprises - Trade Effects and Policy Implications. OECD Trade Policy Papers, 147. Available from internet: http://www.oecd-ilibrary.org/docserver/ download/5k4869ckqk7l.pdf?expires=1457341683\&id=id\&accname=guest\&checksum=7D288BE9E9FD1577734 A96FCFD19774A. https://doi.org/10.1787/5k4869ckqk71-en

Loke, C. H., Ismail, S., \& Hamid, F. A. (2016). The Perception of Public Sector Auditors on Performance Audit in Malaysia: An Exploratory Study. Asian Review of Accounting, 24(1), 90-104. http://dx.doi.org/10.1108/ARA12-2013-0082.

MacCarthaigh, M. (2009). The Corporate Governance of Commercial State-owned Enterprises in Ireland. CPMR Research Report, 9. Available from internet: http://www.ipa.ie/pdf/cpmr/reports/CPMR_RR9_Corporate_Governance_of_ Stateowned_Enterprises_Ireland.pdf.

Menozzi, A., Urtiaga, G. M., \& Vannoni, D. (2012). Board Composition, Political Connections, and Performance in Stateowned Enterprises. Industrial and Corporate Change, 21(3), 671-698. https://doi.org/10.1093/icc/dtr055.

Ministry of Economic Development and Trade of Ukraine (2016). Ministry of Economic Development and Trade of Ukraine Published the First Review of the 100 Largest State Enterprises. Available from internet: http://www.me.gov. ua/News/Detail?lang=en-GB\&id=5fe878f1-885c-4690-ab84-6c612b0504e2\&title=MinistryOfEconomicDevelop mentAndTradeOfUkrainePublishedTheFirstReviewOfThe100-LargestStateEnterprises.

Most, K. S. (1987). A Selective History of Management Audit. Managerial Audit Journal, 2(3), 26-29. http://dx.doi. org/ 10.1108/eb017601. 
Nakrosis, V., \& Martinaitis, Z. (2011). Lithuanian Agencies and Other Public Sector Organizations: Organizations, Autonomy, Control and Performance. Vilnius: Vilnius University Press.

Nguyen, X. (2015). On the Efficiency of Private and State-Owned Enterprises in Mixed Markets. Economic Modelling, 50, 130-137. http://doi.org/10.1016/j.econmod.2015.06.011.

OECD. (2015). OECD Guidelines on Corporate Governance of State-owned Enterprises. Paris: OECD Publishing. Available from internet: http://www.oecd.org/corporate/ca/corporategovernanceofstate-ownedenterprises/3480 3211.pdf.

OECD. (2015). OECD Review of Corporate Governance of State-owned Enterprises: Lithuania. Available from internet: http://www.oecd.org/daf/ca/Lithuania_SOE_Review.pdf.

Orzekauskas, P., \& Smaiziene, I. (2009). Organizacijų valdymo ir administravimo audito modeliavimas (Designing a Framework for Audit Organizations' Management and Administration). Ekonomika ir vadyba (Economics and Management), 14, 1163-1169.

Platts, K. W., \& Gregory, M. J. (1990). Manufacturing Audit in the Process of Strategy Formulation. International. Journal of Operations \& Production Management, 10(9), 5-26. http://dx.doi.org/10.1108/EUM0000000001 264.

Reddy, K. S., Xie, E., \& Huang, Y. (2016). Cross-border Acquisitions by State-owned and Private Enterprises: A Perspective from Emerging Economies. Journal of Policy Modeling, 38(6), 1147-1170. http://doi.org/10.1016/j.jpolmod. 2016.10.002.

Roncea, C. (2016). Management Systems Audit in the Annex SL Context. The TQM Journal, 28(5), 786-796. http://dx.doi.org/10.1108/TQM-10-2015-0129.

Salkic, I. (2014). Impact of Strategic Planning on Management of Public Organizations in Bosnia and Herzegovina. Interdisciplinary Description of Complex Systems, 12(1), 61-77. http://hrcak.srce.hr/114925. https://doi.org/10. 7906/indecs.12.1.4

Sokol, D. D. (2009). Competition Policy and Comparative Corporate Governance of State-owned Enterprises. Brigham Young University Law Review, 1713-1812. http://scholarship.law.ufl.edu/facultypub/147.

Tophoff, V. (2014). Revision of OECD Guidelines on Corporate Governance of State-owned Enterprises. International Federation of Accountants. Available from internet: https://www.ifac.org/global-knowledge-gateway/governance/ discussion/revision-oecd-guidelines-corporate-governance-state.

Verhoest, K., Roness, P., Verschuere, B., Rubecksen, K., \& MacCarthaigh, M. (2010). Autonomy and Control of State Agencies: Comparing States and Agencies. Basingstoke: Palgrave Macmillan. https://doi.org/10.1057/978 0230277274

VI Turto bankas. (2014). Lietuvos valstybes valdomu imoniu veikla 2014 metais: tarpine ataskaita (Activity of Lithuanian State-owned Enterprises in 2014: Interim Report). Available from internet: http://vkc.turtas.lt/static/uploads/ ataskaitos/2014_met_12_mnesi_VV_ataskaita_patikslinta_20150520.pdf.

VI Turto bankas. (2015). Lietuvos valstybes valdomu imoniu veikla 2015 metais: tarpine ataskaita. (Activity of Lithuanian State-owned Enterprises in 2015: Interim Report). Available from internet: http://vkc.turtas.lt/static/ uploads/ataskaitos/2015_met_9_mnesi_VV_ataskaita.pdf.

Wubbelmann, K. (2001). Unternehmenskontext, Teams und Managerleistung Systematisch Analysieren. In Management Audit. Liederbach: Springer, 37-85. https://doi.org/10.1007/978-3-322-90962-6_3

Wubbelmann, K. (2009). Herausforderung Management Audit: Erfolgsleitfaden fur Teilnehmer. Wiesbaden: Springer Science \& Business Media. https://doi.org/10.1007/978-3-8349-8766-2

Yang, K. (2012). Further Understanding Accountability in Public Organizations: Actionable Knowledge and the StructureAgency Duality. Administration \& Society, 44(3), 255-284. http://dx.doi.org/10.1177/0095399711417699.

The article has been reviewed.

Received in April, 2017; accepted in October, 2017. 